\title{
Analisis Gaya Berpikir Matematis Berdasar Teori Mental-Self Government (MSG) Ditinjau Dari Dimensi Pembelajaran Sternberg
}

\author{
Tri Rahayu Handayani ${ }^{{ }^{*}}$, Siti Khoiruli Ummah ${ }^{2}$, Dwi Priyo Utomo ${ }^{3}$ \\ ${ }^{1,2,3}$ Program Studi Pendidikan Matematika, Universitas Muhammadiyah Malang \\ Jalan Raya Tlogomas No. 246, Malang 65144, Indonesia \\ "E-mail: rahayuhandayanitri@gmail.com, Telp: +6282132891362
}

Article received : 28-12-2018, article revised : 14-03-2019, article published: 31-03-019

DOI: $10.25273 /$ jipm.v7i2.3599

\begin{abstract}
Abstrak
Penelitian ini bertujuan untuk mengidentifikasi dan menganalisis gaya berpikir matematis mahasiswa Semester V Jurusan Pendidikan Matematika Universitas Muhammadiyah Malang dalam menyelesaikan soal bertipe High Order Thinking Skill (HOTS). Istilah tersebut untuk selanjutnya dapat diartikan sebagai kemampuan berpikir tingkat tinggi. Penelitian ini berjenis deskriptif dengan data kualitatif berupa hasil tes mahasiswa pada Mata Kuliah Struktur Aljabar. Jumlah mahasiswa yang diberikan tes bertipe tingkat tinggi berjumlah 22 orang yang direduksi menjadi 8 orang. Hasil penelitian ini didasarkan pada karakteristik gaya berpikir matematis ditinjau dari dimensi pembelajaran dan diidentifikasi kembali untuk mendapatkan jumlah mahasiswa yang memiliki gaya berpikir liberal dan konservatif. Mahasiswa dengan gaya berpikir konservatif menyelidiki subgrup dengan menggunakan definisi subgrup yaitu menggunakan langkah-langkah pembuktian grup antara lain tertutup, asosiatif, mempunyai elemen identitas dan invers. Gaya berpikir matematis tipe konservatif cenderung menggunakan strategi penyelesaian yang telah dikenal dan dilakukan sebelumnya. Mahasiswa dengan gaya berpikir liberal menyelidiki subgrup dengan menggunakan Teorema One Step Subgroup Test atau teorema satu langkah dan Two Step Subgroup Test atau teorema dua langkah. Mahasiswa dengan gaya berpikir matematis tipe liberal menggunakan pengetahuan terbaru yang diperolehnya sehingga pengetahuan lama diadaptasi.
\end{abstract}

Kata Kunci: gaya berpikir matematis, liberal, konservatif, soal tingkat tinggi

\begin{abstract}
This research is aimed to identify andanalyze the mathematical thinking style of $V$ Semester student of mathematics education department, University of Muhammadiyah Malang in resolving questions with High Order Thinking Skill (HOTS, kemampuan berpikir tingkat tinggi). Thisdescriptive study uses qualitative data in the form of student test results on Algebraic Structures Courses. The number of students tested by question with High Order Thinking Skill amounted to 22studentsthat then were reduced to 8 men.The results of this research were based on the characteristics of the mathematical thinking style in terms of the dimensions of learning and then they were identified again to obtain students with conservative and liberal thinking style. The students with conservative thinking styles investigated subgroup using the definition of subgroup namely, using proof measures of group, such as close, associative, having identity element and inverse. Conservative mathematical thinking styles tend to use the strategies of solving problems that have been known and done before. The students with liberal thinking style investigatedsubgroupby using the theorem of One Step Subgroup Testand Two Steps Subgroup Test. The students with liberalmathematical thinkingstyles using the latest knowledge acquired so that the old knowledge was adapted.
\end{abstract}

Keywords: mathematical thinking styles, liberal, conservative, high-ordered thinking problems 


\section{PENDAHULUAN}

Istilah gaya dapat didefinisikan sebagai cara seseorang dalam berekspresi. Pengaitan gaya dalam pendidikan adalah bentuk ekspresi hasil pembelajaran berdasarkan pada pemahaman yang telah diperoleh. Selain gaya belajar (learning styles) (Lehmann \& Ifenthaler, 2012) dalam pendidikan, terdapat gaya mengajar (teaching styles) (Ibrahim \& Ahmad, 2016) dan gaya berpikir (thinking styles) (Caroli, Elvira, \& Caroli, 2012). Gaya berpikir (thinking styles) dikenal sebagai dominansi otak yang dapat membuat seseorang memilih cara atau strategi dalam menyelesaikan masalah yang sedang terjadi dan disesuaikan dengan kemampuannya (AlGhraibeh, 2015). Gaya berpikir merupakan teknik berbeda-beda yang digunakan seseorang dalam memproses data (Dİkİcì, 2014) dipelopori oleh Sternberg pada Tahun 1997.

Gaya berpikir seseorang jika dikaitkan dengan pesoalan matematika dinamakan gaya berpikir matematis. Gaya berpikir matematis oleh beberapa peneliti dianggap sebagai proses yang berkaitan dengan kemampuan mental dan hal tersebut erat kaitannya dengan kegiatan menalar, meringkas, menghubungkan, merepresentasi, dan beralih diantara perbedaan representasi, menggambarkan, menyusun, menganalisis, mensintesis, menghubungkan, menggeneralisasi dan membuktikan (Nepal, 2016).

Seseorang yang dihadapkan dengan permasalahan matematika, memiliki cara sendiri dalam memahami masalah serta bagaimana cara menyelesaikannya (AlGhraibeh, 2015). Soal yang berkaitan dengan permasalahan matematika dikategorikan menjadi dua kelompok yaitu permasalahan rutin dan permasalahan non-rutin. Soal berkategori rutin dapat diselesaikan dengan mudah menggunakan cara yang sudah ada sebelumnya (Özcan, İmamoğlu, \& Bayrakl1, 2017). Penemuan solusi yang lebih rumit dari biasanya dengan cara menganalisis soal kemudian memilih berbagai teorema maupun definisi yang mengarah pada jawaban adalah ciri penyelesaian soal non-rutin (Pantziara, Gagatsis, \& Pitta-Pantazi, 2004). Penyebaran gaya berpikir matematis mahasiswa yang beragam pada sebuah pembelajaran, membuat pendidik atau pengajar harus memilih serta menerapkan berbagai jenis metode, model bahkan media pembelajaran yang dapat mengeksplorasi semua jenis gaya berpikir matematis mahasiswa tersebut agar mencapai hasil belajar maksimal (Vale \& Barbosa, 2017). Pendidik yang fokus pada satu model pembelajaran umum, akan mengakibatkan mahasiswa dengan gaya berpikir matematis umum yang dapat teridentifikasi hasil belajarnya (Sharma,P \& Neetu,2011). Jika hal tersebut terjadi, maka tujuan pembelajaran tidak dapat tersampaikan dengan baik.

Gaya berpikir atau thinking styles bukan teori baru di dunia keilmuwan, teori tersebut pertama kali dicetuskan oleh Grigorenko \& Sternberg pada tahun 1997 dikenal dengan Mental-Self Government (MSG) atau ilmu otonomi mental dan ditujukan pada gaya berpikir. MSG didasarkan pada metafora antara cara individu dalam mengorganisir pemikiran dan cara masyarakat diatur (Moutsios-Rentzos \& Simpson, 2010). Teori tersebut mengelompokkan 13 gaya berpikir pada 5 dimensi yaitu, dimensi fungsi terdiri dari tipe berpikir legislatif (orang-orang yang mandiri dan mampu menyelesaikan tugas dengan cara yang terpisah), eksekutif (orang-orang yang mentaati aturan dan kebiasaan) dan yudisial (berdasarkan aturan dan sistem yang diperlukan atau valid) (Aljojo, 2017; Sternberg, 2005). Dimensi bentuk dengan gaya berpikir hierarki (memprioritaskan pada satu tugas), oligarki (bekerja pada beberapa tugas dan tidak ada yang diutamakan), monarki (mengerjakan satu tugas dalam satu waktu) dan anarki (mengerjakan tugas apa saja yang diberikan) (Emamipour \& Esfandabad, 2013) .

Dimensi yang terpusat pada tingkatan dengan tipe gaya berpikir global (orang-orang yang lebih suka berurusan dengan masalah besar dan abstrak daripada masalah-masalah yang detail) (Caroli et al., 2012) dan lokal (orangorang yang lebih menyukai masalah dengan penyelesaian yang detail) (Turki, 2012). Dimensi lingkungan mengelompokkan gaya berpikir pada dua hal yaitu gaya berpikir internal (menyelesaikan masalah secara mandiri) dan gaya berpikir eksternal (lebih suka mengerjakan sesuatu dengan tim), sedangkan dimensi terakhir yaitu dimensi pembelajaran memuat gaya berpikir liberal (menggunakan cara yang baru dalam menyelesaikan masalah) dan konservatif (menggunakan cara lama atau yang sudah ada dalam menyelesaikan masalah) (Emamipour \& Esfandabad, 2013) (Zhang, 2017). 
Teori gaya berpikir dapat berubah sesuai dengan perkembangan zaman. Cara berpikir seseorang dapat berubah berdasarkan masalah yang dihadapi, waktu terjadi, lingkungan sekitar serta kebiasaan yang dilakukan (Emamipour \& Esfandabad, 2013). Bentuk-bentuk gaya berpikir tersebut dapat dipilih atau diklasifikasikan sesuai dengan kebutuhan. Gaya berpikir seseorang dapat menentukan dominansi otak yang ada pada orang tersebut. Dominansi otak kanan dan otak kiri seseorang berdampak pada aktivitas yang biasa dilakukan. Seseorang yang dominan pada otak bagian kanan lebih menyukai kegiatan menyalin desain, mendeskripsikan bentuk, memahami bentukbentuk geometri, membaca sikap seseorang dari wajah, mendengarkan musik, dan mengekspresikan perasaan. Sedangkan seseorang yang lebih dominan pada otak bagian kiri akan terfokus pada kemampuan bahasa, lebih kreatif, serta terbiasa menganalisis (Oflaz, 2011).

Beberapa peneliti mengklasifikasikan kembali teori Sternberg berdasarkan dominansi otak. Seseorang dengan rasa ingin tahu yang tinggi dan ingin mencari pengalaman dalam setiap permasalahan yang ditemui dapat dikelompokkan pada gaya berpikir legislatif, yudisial dan liberal, sedangkan orang dengan tingkat emosional yang tidak stabil, mudah malu, pesimis bahkan memiliki tingkat percaya diri yang rendah digolongkan pada gaya berpikir eksekutif dan konservatif (Caroli et al., 2012). Berdasarkan hal tersebut, individu yang terbiasa melakukan hal-hal baru dikatakan dominan pada otak kiri sedangkan individu yang lebih suka dengan hal-hal yang sudah ada sebelumnya merupakan individu dengan dominanansi pada otak kanan. Peran dominan otak tersebut juga berpengaruh pada bagaimana cara seseorang dalam belajar, menanggapi serta menyelesaikan masalah (Sharma, 2011). Teori Sternberg yang berkaitan dengan pembelajaran adalah dimensi pembelajaran dengan dua kategori penggolongan yaitu gaya berpikir liberal dan konservatif.

Gaya berpikir liberal dan konservatif dapat dikaitkan secara langsung dengan permasalahan matematika. Seseorang dengan gaya berpikir liberal cenderung menyukai penyelesaian masalah dengan cara yang baru berdasarkan pengetahuan yang telah dimiliki sebelumnya (Moutsios-Rentzos \& Simpson, 2010). Seseorang yang memiliki gaya berpikir konservatif, akan melihat persoalan matematika dan menyelesaikannya berdasarkan aturan yang sudah biasa ditemui, kemudian mengkategorikannya untuk mengubah beberapa hal yang mungkin di rubah (Turki, 2012).

Matematika menjadi hal yang menakutkan bagi pelajar di Indonesia. Tanpa disadari, setiap kegiatan di kehidupan ini sangat bergantung dengan matematika dan dikenal dengan Mathematical Problem. Permasalahan tersebut jika dikaitkan dengan proses pembelajaran merupakan proses mendalami pertanyaan dengan membaca sungguh-sungguh untuk memahami pertanyaan itu (Onal, Inan, \& Bozkurt, 2017). Dengan memahami pertanyaan tersebut, mahasiswa mampu menemukan cara dalam menyelesaikannya dan merupakan proses berpikir sesuai dengan gaya berpikir, kebiasaan dan kemampuan yang mahasiswa miliki. Matematika memiliki beberapa karakteristik yaitu 1) memiliki objek kajian yang asbtrak, 2) bertumpu pada kesepakatan, 3) berpola pikir deduktif, 4) kosisten dalam sistem, 5) memiliki simbol yang kosong dalam arti, 6) memperhatikan semesta pembicaraan (Soedjadi, 2007).

Pola pikir deduktif akan membawa permasalahan matematika dari kehidupan sehari-hari untuk dibuat bentuk penyelesaiannya secara lebih matematis dan terstruktur. Kenyataan yang terjadi, mahasiswa akan menggunakan rumus atau tahap penyelesaian yang sudah tersedia untuk kemudian melihat bentuk permasalahan yang nyata di kehidupan sehari-hari. Terdapat berbagai cara untuk menyelesaikan persoalan matematika dan cara tersebut berhubungan dengan gaya berpikir yang dimiliki oleh setiap individu. Open-ended, Closed-ended, Procedural, dan High Order Thinking merupakan beberapa contoh dari cara menyelesaikan persoalan matematika. Penyelesaian dapat dikatakan Open-ended jika individu atau siswa sangat mungkin untuk menyelesaikan masalah menggunakan cara yang dipilih sendiri (Gafur, Indah Mawarni, Sudia, 2015)

Seseorang yang memilih untuk menyelesaikan persoalan dengan menggunakan rumus atau mengerahkan pikirannya pada logika, maka orang tersebut memilih cara menyelesaikan masalah dengan Closed-ended (Lin, 2013). Sedangkan Procedural merupakan teknik penyelesaian masalah yang mengharuskan individu untuk menyesuaikannya 
menggunakan metode langkah demi langkah. High Order Thinking didefinisikan sebagai cara seseorang yang mampu menghubungkan pembelajaran dengan pengetahuan lain yang telah didapatkan untuk mengasosiasikannya (Kusuma, Rosidin, \& Suyatna, 2017). High Order Thinking adalah berpikir yang berada pada tingkatan tertinggi daripada sekedar menghafal, oleh karena itu diperlukan tugas yang sulit untuk memamahami, menghubungkan satu dengan yang lain, mengkategorikan dan meletakkan semuanya pada langkah yang baru dan diaplikasikan sebagai solusi untuk permasalahan yang baru (Development, Ghasempour, Kashefi, \& Miri, 2012)

Pembelajaran matematika tidak hanya sekedar pemberian materi, asal mula rumus dan contoh soal, namun harus disertai dengan pengaplikasian di kehidupan sehari-hari. Proses belajar tersebut harus dilakukan secara terus menerus untuk melatih gaya berpikir yang bergantung pada rumus tanpa mengetahui pengaplikasinya. Pentingnya penerapan gaya berpikir tingkat tinggi membuat guru harus menyediakan soal yang tidak dijawab secara sederhana (soal non-rutin), namun melalui strategi pemecahan masalah yang sistematis (Ariandari, 2015). Soal dengan pola pertanyaan 'apa' dapat ditingkatkan menjadi, 'bagaimana', dan 'kenapa'. Peningkatan pola pertanyaan akan berdampak pada meningkatnya pola pikir mahasiswa tersebut secara bertahap.

Kemampuan berpikir tingkat tinggi mengarahkan individu membaca kembali persoalan yang ada dan menghubungkan pengetahuan yang dimiliki untuk menjawab soal atau menggunakan solusi yang telah ditemukan untuk menjawab persoalan baru. Menerapkan kemampuan tersebut sangat penting karena mampu meningkatkan pengetahuan yang dimiliki dan hal tersebut dapat digunakan untuk menjawab lebih dari satu pertanyaan. Penerapan kemampuan berpikir tingkat tinggi dalam pembelajaran menuntut pemilihan dan penerapan metode yang sesuai dengan tujuan pembelajaran dan mencakup seluruh kemampuan berpikir mahasiswa.

Model penyelesaian masalah yang menuntut kemampuan berpikir tingkat tinggi pada seseorang dengan gaya berpikir liberal maupun konservatif dapat membantu untuk mengidentifikasi lebih jauh tentang pengetahuan yang dimiliki serta cara berpikir dengan lebih baik. Seseorang dengan gaya berpikir liberal terbiasa mencoba hal baru sebagai bentuk penyelesaian masalah matematika yang dihadapi, sedangkan individu dengan gaya berpikir konservatif cenderung menggunakan cara yang sudah diberikan sebelumnya. Dampak dari perbedaan gaya berpikir tersebut akan terlihat pada hasil belajarnya (Makulua \& Toenlioe, 2016). Penggunaan kemampuan berpikir tingkat tinggi merupakan salah satu cara menyeimbangkan hasil belajar individu dengan gaya berpikir yang berbeda (Ita, 2018).

Menguji kemampuan berpikir tingkat tinggi dapat dilakukan dengan menyediakan permasalahan matematika dan seseorang dikatakan memiliki kemampuan tersebut jika mampu menyelesaikan soal menggunakan definisi atau teorema (Budiman,Agus \& Jailani, 2014). Mata kuliah struktur aljabar merupakan salah satu mata kuliah yang dapat mengarahkan mahasiswa untuk menggunakan kemampuan berpikir tingkat tinggi. Sebelum menempuh mata kuliah struktur aljabar mahasiswa terlebih dahulu menumpuh materi aljabar linier, logika dasar serta himpunan. Materi struktur aljabar yang dipilih adalah grup dan subgrup yang erat kaitannya dengan definisi maupun teorema.

Subgrup didefinisikan oleh Suatu Himpunan G merupakan grup dengan operasi *. Suatu subset $H$ dari $G$ disebut subgrup dari operasi biner * yang terdefinisi dari $G$ (Baylis \& Gallian, 1991). Sebuah himpunan dikatakan subgrup apabila memenuhi sifat-sifat dari grup yaitu tertutup, asosiatif, mempunyai elemen identitas dan mempunyai invers. Definisi dikembangkan menjadi dua teorema yang disebut dengan teorema satu langkah (one step subgoup test) dan teorema dua langkah (two step subgroup test).

Teorema satu langkah (one step subgroup test) menyatakan bahwa Diketahui H subset dari Subgrup dari Grup $G$ disebut subgrup dari $G$ jika dan hanya jika:

\section{H tidak kosong}

2. $\boldsymbol{a} \in \boldsymbol{H}$ dan $\boldsymbol{b} \in \boldsymbol{H}$ mengakibatkan $\boldsymbol{a} \boldsymbol{b}^{\mathbf{- 1}} \in \boldsymbol{H}$ (Baylis \& Gallian, 1991)

Teorema dua langkah (two step subgroup test) menyatakan bahwa Suatu subset $H$ dari grup $G$ disebut subgrup dari $G$ jika dan hanya jika kondisi berikut terpenuhi:

\section{H tidak kosong}


2. $\boldsymbol{x} \in \boldsymbol{H}$ dan $\boldsymbol{y} \in \boldsymbol{H}$ mengakibatkan $\boldsymbol{x} y \in \boldsymbol{H}$

3. $\boldsymbol{x} \in \boldsymbol{H}$ mengakibatkan $\boldsymbol{x}^{-\boldsymbol{1}} \in \boldsymbol{H}$

Selain menggunakan definisi tersebut, untuk membuktikan subgrup dapat dilakukan dengan dua cara yaitu, 1) teorema satu langkah dan 2) teorema dua langkah. Berdasarkan pemberian soal tersebut, mahasiswa sebagai objek pada penelitian ini diharapkan mampu menggunakan definisi atau teorema yang telah dipelajari sebelumnya sebagai salah satu cara untuk mengembangkan jawaban.

\section{METODE}

Penelitian ini didasarkan pada peristiwa yang sedang terjadi dan mengacu pada masalahmasalah aktual dan termasuk pada jenis penelitian deskriptif. Pendekatan penelitian yang digunakan adalah kuantitatif dan kualitatif. Data penelitian kuantitatif berupa jumlah mahasiswa yang digolongkan berdasarkan gaya berpikirnya. Penggolongan gaya berpikir dilakukan melalui pembagian soal Struktur Aljabar materi subgrup bertipe kemampuan berpikir tingkat tinggi (HOTS). Soal dibuat menggunakan taxonomy bloom dengan kategori analisis (C5) dan evaluasi (C6). Data kualitatif berupa kategori gaya berpikir mahasiswa yang telah direduksi berdasarkan jawaban dari soal yang diberikan. Subjek penelitian merupakan mahasiswa program studi pendidikan matematika semester $\mathrm{V}$ pada mata kuliah Struktur Aljabar dengan materi subgrup.

Penelitian ini menggunakan dua jenis instrumen yaitu instrumen penelitian berupa soal dengan kemampuan berpikir tingkat tinggi, serta instrumen evaluasi berupa tabel pengelompokkan gaya berpikir mahasiswa (liberal dan koservatif). Pengumpulan data hasil tes mahasiswa bertujuan untuk menganalisis tipe gaya berpikir dengan mereduksi jawaban berdasarkan kategori (1) jawaban benar menggunakan langkah lengkap definisi (2) jawaban benar dengan teorema satu langkah (3) jawaban benar dengan teorema dua langkah

\section{HASIL DAN PEMBAHASAN}

Pengamatan terhadap masalah yang sedang terjadi serta proses pengkajiannya berdasarkan literatur merupakan langkah awal dari penelitian ini. Penelitian difokuskan pada gaya berpikir mahasiswa berdasarkan teori Mental-Self Government pada dimensi pembelajaran. Variabel dalam penelitian ini adalah gaya berpikir mahasiswa yang dikelompokkan melalui soal yang mengarahkan mahasiswa pada kemampuan berpikir tingkat tinggi pada mata kuliah Struktur Aljabar materi subgrup. Soal bertipe High Order Thinking dapat dibuat dengan beberapa jenis, yaitu pilihan ganda, pilihan ganda kompleks (benar/salah, ya/tidak), isian singkat atau melengkapi, jawaban singkat atau pendek dan uraian (Fanani, 2013). Dua kategori gaya berpikir mahasiswa (liberal dan konservatif) dilihat berdasarkan langkah yang digunakan dalam menyelesaikan soal tersebut. Pembuatan soal yang mengacu pada kata kerja Bloom dilakukan berdasarkan kisi-kisi berikut.

Tabel 1. Kisi-Kisi Soal

\begin{tabular}{|c|c|c|c|c|}
\hline $\begin{array}{l}\text { No. } \\
\text { Soal }\end{array}$ & Indikator Soal & $\begin{array}{c}\text { Taksonomi } \\
\text { Bloom }\end{array}$ & Soal & $\begin{array}{c}\text { Tingkat } \\
\text { Kesulitan }\end{array}$ \\
\hline 1 & $\begin{array}{l}\text { Menyelidiki sifat } \\
\text { grup dan subgrup } \\
\text { pada operasi } \\
\text { penjumlahan }\end{array}$ & $\mathrm{C} 5$ & $\begin{array}{l}\text { Diketahui } H=\{a+b i, a, b \in \mathbb{R}, a b \geq 0\} \text {. } \\
\text { Selidiki apakah } H \text { merupakan subgroup dari } \mathbb{C} \\
\text { dengan operasi penjumlahan }\end{array}$ & Sedang \\
\hline 2 & $\begin{array}{l}\text { Menyelidiki aturan } \\
\text { subgrup pada } \\
\text { operasi perkalian }\end{array}$ & $\mathrm{C} 5$ & $\begin{array}{l}H-\{1,-1, i,-i) \text { dengan }(\mathrm{C}, \mathrm{N}) \text { sebagai grup. } \\
\text { Buktikan bahwa } H \text { adalah subgroup dari }(\mathrm{C}, \mathrm{x})\end{array}$ & Mudah \\
\hline 3 & $\begin{array}{l}\text { Menganalisis } \\
\text { definisi subgrup }\end{array}$ & $\mathrm{C} 4$ & $\begin{array}{l}\text { Diketahui } G \text { adalah grup dan } H \text { adalah } \\
\text { subgroup dari } G \text {. Untuk setiap } a \in G \text {, } \\
\text { didefinisikan } a H a^{-1}=\left\{a h a^{-1} \mid h \in H\right\} \text {. } \\
\text { Tunjukkan bahwa } a H a^{-1} \text { adalah subgroup dari } \\
G \text {. }\end{array}$ & Sedang \\
\hline
\end{tabular}




\begin{tabular}{|c|c|c|c|c|}
\hline 4 & $\begin{array}{l}\text { Menyelidiki konsep } \\
\text { subgrup pada irisan } \\
\text { dua himpunan }\end{array}$ & $\mathrm{C} 5$ & $\begin{array}{l}\text { Buktikan jika } H \leq G \text { dan } K \leq G \text { adalah } \\
\text { subgroup maka }(H \cap K) \leq G\end{array}$ & Sulit \\
\hline
\end{tabular}

Membuktikan sebuah himpunan termasuk subgrup dapat menggunakan beberapa cara yaitu 1) definisi atau teorema, 2) one step subgroup test, 3) two step subgroup test. Pembuktian menggunakan definisi dilakukan dengan beberapa langkah yaitu membuktikan himpunan tersebut adalah sebuah grup yang bersifat asosiatif, tertutup serta memiliki invers dan identitias. Langkah one step subgroup test dan two step subgroup test dilakukan dengan membuktikan satu atau dua dari definisi suatu himpunan dikatakan grup atau subgrup. Tipe jawaban mahasiswa berupa definisi, one step subgroup test dan two step subgroup test direduksi menjadi tipe gaya berpikir dengan kategori sebagai berikut: 1) mahasiswa yang memilih membuktikan grup atau subgrup menggunakan keempat poin pada definisi atau teorema dikategorikan memiliki gaya berpiki konservatif, 2) mahasiswa yang memilih menjawab soal dengan membuktikan satu definisi atau dua definisi dikelompokkan pada jenis gaya berpikir liberal.

Pengambilan subjek penelitian pada mata kuliah Struktur Aljabar materi subgrup test dilakukan pada mahasiswa pendidikan matematika semester $\mathrm{V}$ kelas $\mathrm{C}$ dengan jumlah 22 mahasiswa. Pengelompokkan jawaban siswa dan gaya berpikir setiap soal dapat dilihat pada Tabel

2 . berikut.

Tabel 2 Hasil Reduksi Data

\begin{tabular}{|c|c|c|c|c|}
\hline \multirow{2}{*}{$\begin{array}{l}\text { Nomor } \\
\text { Soal }\end{array}$} & \multirow{2}{*}{ Tipe Jawaban Siswa } & \multicolumn{2}{|c|}{ Jenis Gaya Berpikir } & \multirow{2}{*}{$\begin{array}{c}\text { Jumlah } \\
\text { Mahasiswa }\end{array}$} \\
\hline & & Liberal & Konservatif & \\
\hline \multirow{4}{*}{1} & $\begin{array}{l}\text { Jawaban benar dan } \\
\text { lengkap }\end{array}$ & \multirow{3}{*}{$\begin{array}{c}\text { Jawaban } \\
\text { menggunakan } \\
\text { langkah one step } \\
\text { subgroup test atau } \\
\text { two step subgroup } \\
\text { test }\end{array}$} & \multirow{3}{*}{$\begin{array}{c}\text { Jawaban } \\
\text { menggunakan } \\
\text { definisi atau } \\
\text { teorema lengkap }\end{array}$} & \\
\hline & $\begin{array}{l}\text { Jawaban benar dan } \\
\text { kurang lengkap }\end{array}$ & & & 1 \\
\hline & $\begin{array}{l}\text { Jawaban kurang benar } \\
\text { dan kurang lengkap }\end{array}$ & & & 11 \\
\hline & Jumlah Mahasiswa & 2 & 10 & \\
\hline \multirow[t]{4}{*}{2} & $\begin{array}{l}\text { Jawaban benar dan } \\
\text { lengkap }\end{array}$ & \multirow{3}{*}{$\begin{array}{c}\text { Jawaban } \\
\text { menggunakan } \\
\text { langkah one step } \\
\text { subgroup test atau } \\
\text { two step subgroup } \\
\text { test }\end{array}$} & \multirow{3}{*}{$\begin{array}{c}\text { Jawaban } \\
\text { menggunakan } \\
\text { definisi atau } \\
\text { teorema lengkap }\end{array}$} & \\
\hline & $\begin{array}{l}\text { Jawaban benar dan } \\
\text { kurang lengkap }\end{array}$ & & & 7 \\
\hline & $\begin{array}{l}\text { Jawaban kurang benar } \\
\text { dan kurang lengkap }\end{array}$ & & & 8 \\
\hline & Jumlah & 4 & 11 & \\
\hline \multirow[t]{4}{*}{3} & $\begin{array}{l}\text { Jawaban benar dan } \\
\text { lengkap }\end{array}$ & \multirow{3}{*}{$\begin{array}{c}\text { Jawaban } \\
\text { menggunakan } \\
\text { langkah one step } \\
\text { subgroup test atau } \\
\text { two step subgroup } \\
\text { test }\end{array}$} & \multirow{3}{*}{$\begin{array}{c}\text { Jawaban } \\
\text { menggunakan } \\
\text { definisi atau } \\
\text { teorema lengkap }\end{array}$} & 1 \\
\hline & $\begin{array}{l}\text { Jawaban benar dan } \\
\text { kurang lengkap }\end{array}$ & & & 1 \\
\hline & $\begin{array}{l}\text { Jawaban kurang benar } \\
\text { dan kurang lengkap }\end{array}$ & & & 8 \\
\hline & Jumlah & 6 & 4 & \\
\hline
\end{tabular}




\begin{tabular}{|c|c|c|c|c|}
\hline \multirow[t]{4}{*}{4} & $\begin{array}{l}\text { Jawaban benar } \\
\text { dan lengkap }\end{array}$ & \multirow{3}{*}{$\begin{array}{c}\text { Jawaban } \\
\text { menggunakan } \\
\text { langkah one } \\
\text { step subgroup } \\
\text { test atau two } \\
\text { step subgroup } \\
\text { test }\end{array}$} & \multirow{3}{*}{$\begin{array}{c}\text { Jawaban menggunakan } \\
\text { definisi atau teorema } \\
\text { lengkap }\end{array}$} & 2 \\
\hline & $\begin{array}{l}\text { Jawaban benar } \\
\text { dan kurang } \\
\text { lengkap }\end{array}$ & & & 3 \\
\hline & $\begin{array}{l}\text { Jawaban kurang } \\
\text { benar dan kurang } \\
\text { lengkap }\end{array}$ & & & 5 \\
\hline & Jumlah & 3 & 7 & \\
\hline
\end{tabular}

Setiap hasil reduksi data mahasiswa dari tabel diatas diambil jawaban yang benar dan lengkap atau mendeketai benar dan lengkap di setiap tipe gaya berpikir. Soal dengan tingkat kesulitan yang berbeda membuat mahasiswa menggunakan penyelesaian yang berbeda dan dari tabel diatas dapat dilihat bahawa satu mahasiswa dapat memiliki gaya berpikir yang berbeda untuk setiap jawabannya. Pada soal nomor 1 dari 12 mahasiswa yang menjawab terdapat 2 mahasiswa yang dikategorikan memiliki gaya berpikir liberal dan 10 mahasiswa dengan gaya berpikir konservatif. Lembar jawaban milik WS yang mendekati benar untuk gaya berpikir liberal dapat dilihat pada Gambar 1. berikut.

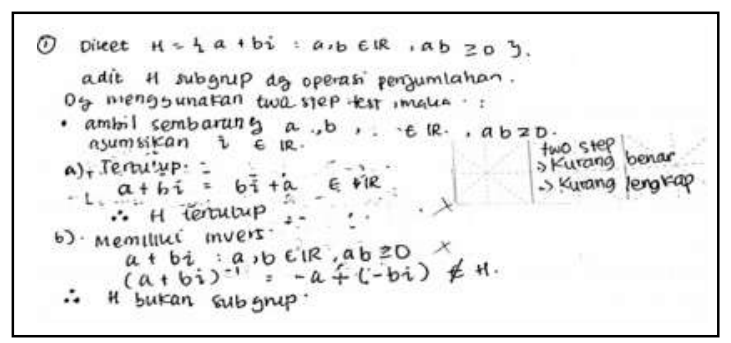

Gambar 1. Jawaban Mahasiswa Tipe Berpikir Liberal

Pada Gambar 1, WS menjawab soal menggunakan langkah two step subgroup test yang merupakan teorema dan baru diajarkan (Emamipour \& Esfandabad, 2013). Kesimpulan jawaban yang diberikan benar, namun proses pengerjaannya masih terdapat kekurangan. Membuktikan subgrup menggunakan two step test harus menunjukkan $a b \in H$ dan $a^{-1} \in H$. Cara yang dipilih WS dalam membuktikan himpunan memiliki invers memiliki kekurangan, mahasiswa telah menuliskan bahwa ia akan mencari invers dari $(a+b)$, namun yang dilakukan adalah mengoperasikan $(a+b)$ dengan pangkat negatif, dimana operasi pangkat negatif dan invers bilangan adalah hal yang berbeda. Pola berpikir WS dianggap liberal karena memilih membuktikan sifat subgrup menggunakan two step subgroup test.

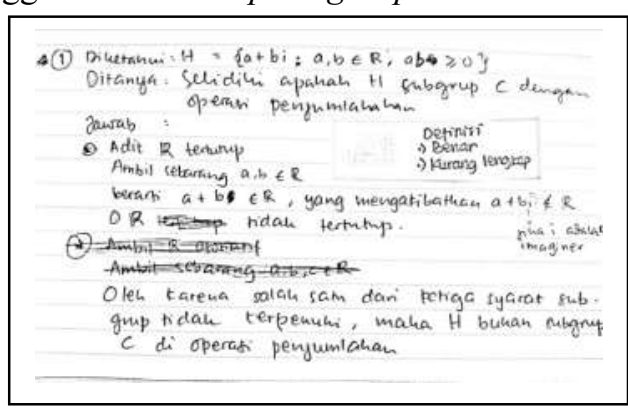

Gambar 2. Jawaban Mahasiswa Tipe Gaya Berpikir Konservatif

Berbeda dari jawaban yang tertera pada Gambar 1., Gambar 2 menunjukkan mahasiswa MS menjawab soal menggunakan definisi dan hal tersebut sudah ada sebelumnya (Zhang, 2017). Mahasiswa tersebut megambil sebarang nilai untuk membuktikan himpunan sebagai grup. Alasan yang disertakan sudah benar yaitu karena terdapat bilangan imajiner dalam himpunan tersebut yang membuat operasi penjumlahan tidak mungkin bersifat tertutup. Namun, beberapa langkah untuk membuktikan himpunan tersebut grup belum lengkap. MS belum mencantumkan langkah yang membuktikan bahwa himpunan bersifat asosiatif, serta memiliki invers dan identitas. Namun WS mampu membuktikan bahwa $\mathrm{H}$ bukan subgrup dari bilangan kompleks pada operasi penjumlahan dan hal tersebut membuktikan bahwa MS pada soal nomor 2 memiliki tipe gaya berpikir konservatif. Pembahasan difokuskan pada mengaitkan data dan hasil analisisnya dengan permasalahan atau tujuan penelitian dan konteks teoretis yang lebih luas. Dapat juga pembahasan merupakan 
jawaban pertanyaan mengapa ditemukan fakta seperti pada data.

Mahasiswa dengan tipe gaya berpikir liberal dan konservatif pada soal nomor 2 dapat dilihat pada Gambar 3. berikut:

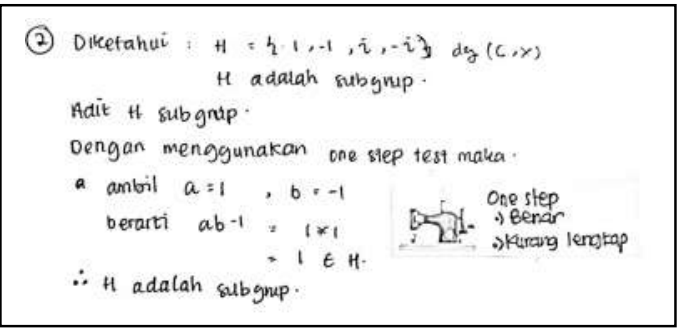

Gambar 3. Jawaban Mahasiswa Tipe Berpikir Liberal

Gambar 3. merupakan jawaban $\mathrm{MN}$ yang mengerjakan soal nomor 2 menggunakan langkah one step test . One step test merupakan teorema yang baru diajarkan, dimana mahasiswa tidak perlu membuktikan semua sifat grup namun mengarahkan untuk membuktikan bahwa $\boldsymbol{a b}^{-\mathbf{1}} \in \boldsymbol{H}$ (Emamipour \& Esfandabad, 2013). Namun, sebelum membuktikan subgrup, mahasiswa terlebih dahulu harus membuktikan bahwa himpunan tersebut bersifat grup, dalam hal ini MN belum menyertakan langkah yang dapat membuktikan jika $\mathrm{H}$ adalah grup. Menunjukkan $\boldsymbol{a b}^{-\mathbf{1}} \in \boldsymbol{H}$ dapat dilakukan dengan mengambil bilangan sebarang pada himpunan tersebut dan mahasiswa MN telah melakukan langkah sesuai dengan buku. MN memilih menjawab soal terkait sifat grup menggunakan one step test, membuktikan bahwa mahasiswa tersebut digolongkan pada gaya berpikir tipe liberal.

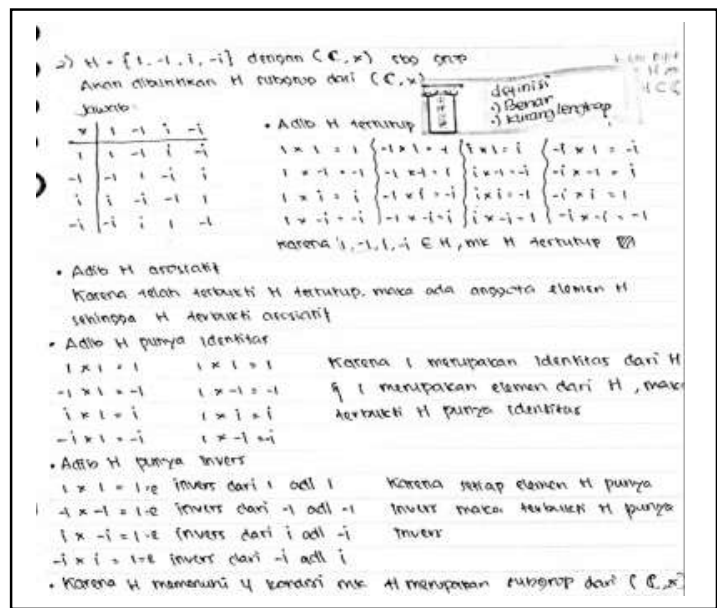

Gambar 4 Jawaban Mahasiswa Tipe Gaya Berpikir Konservatif
Mahasiswa yang tergolong pada tipe gaya berpikir konservatif akan menjawab soal atau sebuah permasalahan berdasarkan aturan yang sudah ada sebelumnya (Zhang, 2017) dan tidak menyukai banyak perubahan. Gaya berpikir tersebut dalam pendidikan membuat mahasiswa akan menjawab soal berdasarkan definisi atau teorema karena tidak memerlukan perubahan. Gambar diatas menunjukkan bahwa mahasiswa NK memiliki tipe gaya berpikir konservatif. Terlihat dari cara yang diambil untuk membuktikan subgrup menggunakan definisi. Langkah pertama, NK membuktikan bahwa $\mathrm{H}$ adalah grup dengan 4 tahapan yaitu tertutup, asosiatif, invers dan identitas. Namun, mahasiswa tersebut kurang menambahkan kesimpulan akhir bahwa $\mathrm{H}$ adalah grup.

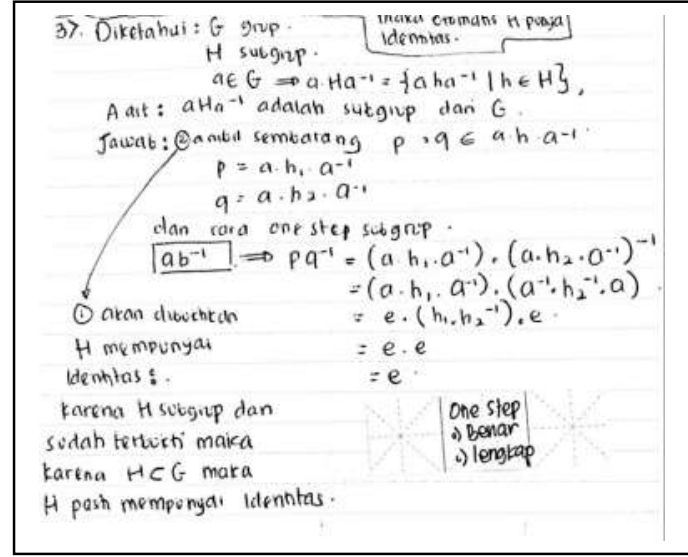

Gambar 5 Jawaban Mahasiswa Tipe Berpikir Liberal

Jumlah mahasiswa yang menjawab soal nomor 3 , terdapat satu mahasiswa yang menjawab benar dan lengkap yaitu AD. Mahasiswa tersebut membuktikan definisi subgrup dengan satu langkah. Pembuktian menggunakan satu langkah merupakan teorema yang baru diajarkan sehingga mahasiswa tidak perlu menggunakan keempat sifat subgrup sebagai pembuktiannya (Emamipour \& Esfandabad, 2013). Konsep serta notasi penulisannya sesuai dengan materi yang ada dibuku. Berdasarkan hal tersebut $\mathrm{AD}$ digolongkan pada gaya berpikir tipe liberal. 


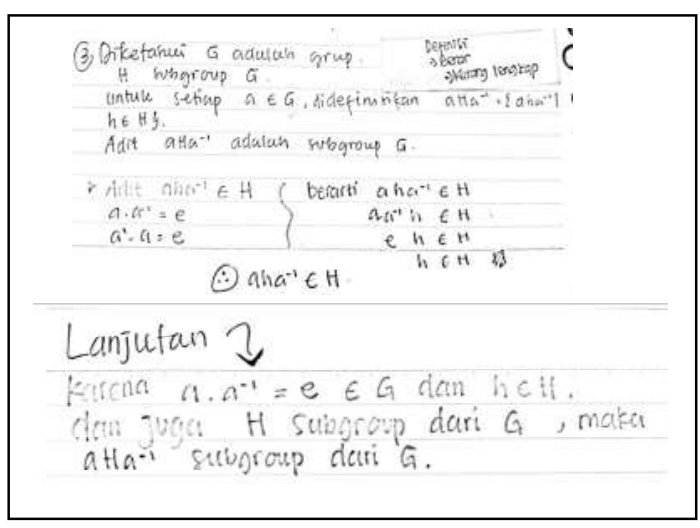

Gambar 6. Jawaban Mahasiswa dengan Gaya Berpikir Tipe Konservatif

Gambar 6. merupakan jawaban mahasiswa FS yang menjawab benar pada soal nomor 3 . Mahasiswa FS menggunakan langkah definisi untuk membuktikan subgrup $a \mathrm{Ha}^{-1}$ adalah subgrup G. Namun, prosedur yang dilakukan FS kurang lengkap karena tidak mencantuman ketiga sifat yang menyatakan suatu himpunan sebagai grup. Pemilihan prosedur pembuktian subgrup menggunakan definisi atau langkahlangkah yang sudah ada sebelumnya dalam menyelesaikan soal menggolongkan mahasiswa FS pada tipe gaya berpikir konservatif (Zhang, 2017). Jawaban mahasiswa untuk soal nomor 4 dan pengelompokkannya berdasarkan gaya berpikir dapat dilihat pada gambar berikut:

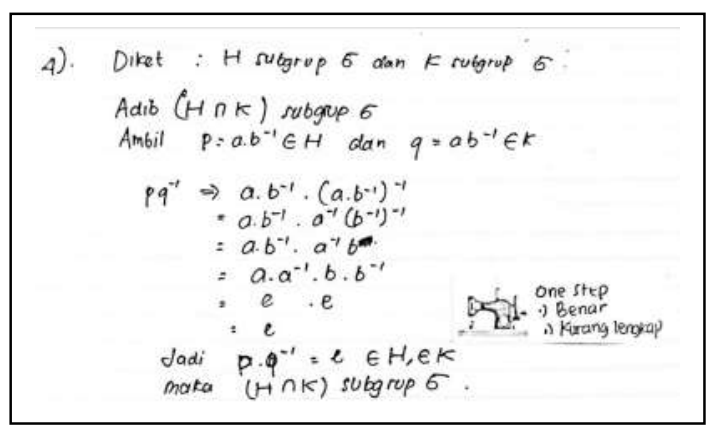

Gambar 7. Jawaban Mahasiswa dengan Gaya Berpikir Tipe Liberal

Seperti yang disebutkan sebelumnya, mahasiswa dikatakan memiliki gaya berpikir tipe liberal jika menyelesaikan soal menggunakan one step test atau two step test. Pada gambar diatas, mahasiswa AH memilih membuktikan sifat subgrup pada irisan dua himpunan menggunakan satu langkah yang merupakan teorema yang baru dijelaskan di kelas (Emamipour \& Esfandabad, 2013). Namun, pada lembar jawaban tersebut masih terdapat kesalahan pada penulisan notasi. Untuk menyatakan $\boldsymbol{e} \in \boldsymbol{H}$ dan $\boldsymbol{e} \in \boldsymbol{K}$ dapat dituliskan dengan $e \in \boldsymbol{H} \cap \boldsymbol{K}$ bukan menggunakan separator $($,$) .$

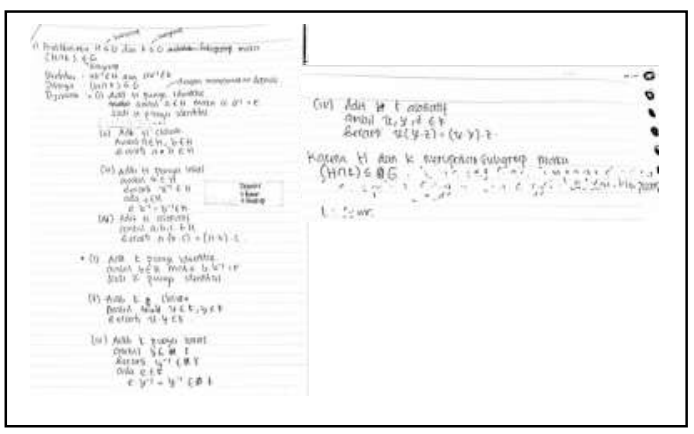

Gambar 8 Jawaban Mahasiswa dengan Gaya Berpikir Tipe Konservatif

Mahasiswa dengan gaya berpikir konservatif akan menjawab soal seperti DA yaitu menggunakan definisi. Mahasiswa DA menyelidiki aturan subgrup menggunakan definisi lengkap dan sesuai dengan materi yang telah diajarkan sebelumnya (Zhang, 2017). Namun, terdapat sedikit kekurangan yaitu belum menyebutkan kesimpulan bahwa $\mathrm{H}$ dan $\mathrm{K}$ adalah grup.

Hasil penelitian menunjukkan mahasiswa Jurusan Pendidikan Matematika dalam menyelesaikan soal bertipe tingkat tinggi materi Struktur Aljabar mempunyai gaya berpikir tipe liberal dan konservatif. Dari total 4 soal tes terdapat 88 kemungkinan jawaban dari 22 mahasiswa. Jawaban tersebut didasarkan pada cara yang digunakan untuk menjawab yaitu definisi atau menggunakan teorema. Jawaban dengan cara penyelesaian definisi sebanyak 32 , sedangkan jawaban dengan cara penyelesaian berupa teorema sebanyak 15 dengan pembagian 12 jawaban berdasarkan cara teorema satu langkah dan 3 jawaban menggunakan cara teorema dua langkah. Mahasiswa yang mempunyai gaya berpikir liberal menyelidiki himpunan sebagai subgrup dengan cara membuktikan syarat-syarat grup, diantaranya tertutup, asosiatif, mempunyai elemen identitas, dan mempunyai invers. Subgrup merupakan himpunan bagian dari suatu himpunan yang telah dinyatakan sebagai grup. Hal ini berarti, elemen identitas dan invers pada grup dan subgrup adalah sama hal tersebut berarti tidak perlu menyelidiki elemen identitas dan 
inversnya. Penyelidikan subgrup menggunakan teorema ini jauh lebih ringkas karena hanya dengan menggunakan invers yang dimiliki pada grup maka penyelidikan hanya menggunakan

langkah kedua dari teorema yaitu $\boldsymbol{a} \in \boldsymbol{H}$ dan

\section{$\boldsymbol{b} \in \boldsymbol{H}$ mengakibatkan $\boldsymbol{a b}^{-\boldsymbol{1}} \in \boldsymbol{H}$.}

Berdasar penjelasan tentang definisi dan teorema tersebut, dapat dirumuskan bahwa mahasiswa dengan gaya berpikir tipe konservatif seringkali ditandai menggunakan definisi untuk menyelidiki subgrup. Mahasiswa yang menggunakan definisi telah terbiasa membuktikan grup sehingga dapat dikatakan menggunakan strategi penyelesaian masalah bertipe tingkat tinggi yang telah diperoleh sebelumnya (Zhang, 2017). Mahasiswa yang menggunakan One Step Subgroup Test dan Two Steps Subgroup Test diklasifikasikan sebagai mahasiswa dengan gaya berpikir tipe liberal. Mahasiswa tersebut mampu mengadaptasi materi baru yang diperolehnya karena ada beberapa hal yang telah dipahami pada grup yaitu elemen identitas dan invers (Ferri, 2012).

\section{SIMPULAN}

Hasil penelitian ini menunjukkan bahwa dari 22 mahasiswa dengan kemungkinan 88 jawaban yang didasarkan pada cara menjawabnya yaitu definisi maupun teorema terdapat 32 jawaban dengan cara definisi dan 15 jawaban dengan teorema (12 menggunakan teorema satu langkah dan 3 menggunakan teorema dua langkah).

Mahasiswa dengan gaya berpikir tipe konservatif menggunakan definisi yaitu empat syarat grup untuk menyelidiki subgrup. Hal ini dikarenakan mahasiswa yang menggunakan definisi telah terbiasa membuktikan grup sehingga dapat dikatakan menggunakan strategi yang telah diperoleh sebelumnya. Mahasiswa yang menggunakan One Step Subgroup Test (teorema satu langkah) dan Two Steps Subgroup Test (teorema dua langkah) dikategorikan sebagai mahasiswa dengan gaya berpikir liberal. Hal ini dikarenakan mahasiswa tersebut mampu mengadaptasi materi baru yang diperolehnya serta menggunakannya dalam menyelesaikan masalah matematika.

\section{DAFTAR PUSTAKA}

AlGhraibeh, A. M. A. (2015). Learning and Thinking Styles Based on Whole Brain Theory in Relation to Emotional Intelligence. OALib, 02(05), 1-14. https://doi.org/10.4236/oalib.1101436

Aljojo, N. (2017). Journal of Technology and Science Education Differences In Styles Of Thinking "In Light Of Sternberg's Theory": A Case Study Of Different Educational Levels In Saudi Arabia, 7(3), 333-346.

Ariandari, W. P. (2015). Mengintegrasikan Higher Order Thinking dalam Pembelajaran Creative Problem Solving, 489-496.

Baylis, J., \& Gallian, J. A. (1991). Contemporary Abstract Algebra. The Mathematical Gazette (Vol. 75). https://doi.org/10.2307/3619533

Budiman, A. (2014). Pengembangan Instrumen Asesmen Higher Order Thinking Skill (HOTS) Pada Mata Pelajaran Matematika SMP Kelas VIII Semester 1, 1(November 2014), 139-151.

Caroli, D., Elvira, M., \& Caroli, M. E. De. (2012). Redalyc.Creativity And Thinking Styles in Arts, Sciences, And Humanities High School.

Development, H. R., Ghasempour, Z., Kashefi, H., \& Miri, S. A. (2012). Higher - Order Thinking via Mathematical Problem Posing Tasks among Engineering Students, 1(1), 41-47.

Dİkİ̇i, A. (2014). Relationships between Thinking Styles and Behaviors Fostering Creativity: An Exploratory Study for the Mediating Role of Certain Demographic Traits, 14(1), 179-201. https://doi.org/10.12738/estp.2014.1.1939

Emamipour, S., \& Esfandabad, H. S. (2013). Developmental study of thinking styles in Iranian students. Procedia - Social and Behavioral Sciences, 84(1997), 17361739. https://doi.org/10.1016/j.sbspro. 2013.07.023

Fanani, M. Z. (2013). Strategi Pengembangan Soal Higher Order Thinking Skill, 57-76.

Ferri, R. B. (2012). Mathematical thinking styles and their influence on teaching and learning mathematics. 12th International Congress on Mathematical ..., 12.

Gafur, Indah Mawarni;Sudia, M. (2015). Meningkatkan Kemampuan Memecahkan 
Masalah Open-Ended Siswa Kelas VII-2 SMPN 3 Kulisusu Melalui Pendekatan Pengajuan Masalah Pada Pokok Bahasan Segi Empat, 3(1), 75-90.

Ibrahim, I., \& Ahmad, A. (2016). Teaching Styles Preferred By Students on Their Achievement in History Subject, 21(6), 47-53. https://doi.org/10.9790/08372106054753

Ita. (2018). Keterampilan Berpikir Tingkat Tinggi dan Hasil Belajar Kognitif Siswa melalui Pembelajaran Kooperatif Berbasis Inkuiri Student' s High Order Thinking Skill and Their Cognitive Achievement Through Cooperative Learning Based on Inquiry, 11, 23-28.

Kusuma, M. D., Rosidin, U., \& Suyatna, A. (2017). The Development of Higher Order Thinking Skill ( Hots ) Instrument Assessment In Physics Study, 7(1), 26-32. https://doi.org/10.9790/7388-0701052632

Lehmann, T., \& Ifenthaler, D. (2012). Influence of students ' learning styles on the effectiveness of instructional interventions. International Conference on Cognition and Exploratory Learning in Digital Age (CELDA), 180-188. Retrieved from http://www.eric.ed.gov/PDFS/ED542718.p df

Lin, W. (2013). The Different Role of Working Memory in Open-Ended Versus ClosedEnded Creative Problem Solving: A DualProcess Theory Account, 25(1), 85-96. https://doi.org/10.1080/10400419.2013.75 2249

Makulua, I. J., \& Toenlioe, A. J. E. (2016). Pengaruh Pembelajaran Kontekstual dan Gaya Berpikir Terhadap Hasil Belajar Sosiologi, 1935-1937.

Moutsios-Rentzos, A., \& Simpson, A. (2010). The thinking styles of university mathematics students. Acta Didactica Napocensia, 3(4), 1-10.

Nepal, B. (2016). Relationship between Mathematical Thinking and Mathematics Achievement. IOSR Journal of Research Mrthod in Education (IOSR-JRME), 6(6), 46-49. https://doi.org/10.9790/7388-
0606044649

Oflaz, M. (2011). The effect of right and left brain dominance in language learning. Procedia - Social and Behavioral Sciences, 15, 1507-1513. https://doi.org/10.1016/j.sbspro.2011.03.32 0

Onal, H., Inan, M., \& Bozkurt, S. (2017). A Research on Mathematical Thinking Skills : Mathematical Thinking Skills of Athletes in Individual and Team Sports, 5(9), 133-139. https://doi.org/10.11114/jets.v5i9.2428

Özcan, Z. Ç., İmamoğlu, Y., \& Bayraklı, V. K. (2017). Analysis of sixth grade students' think-aloud processes while solving a nonroutine mathematical problem. Kuram ve Uygulamada Egitim Bilimleri, 17(1), 129 144. https://doi.org/10.12738/estp.2017.1.2680

Pantziara, M., Gagatsis, A., \& Pitta-Pantazi, D. (2004). The use of diagrams in solving non routine problems. 28Th Conference of the International Group for the Psychology of Mathematics Education, 3(January), 489496. Retrieved from http://www.emis.de/proceedings/PME28/R R/RR103_Pantziara.pdf

Sharma, P. ; N. (2011). A Study Of LearningThinking Style Of Secondary School Students In Relation To Their Academic Achievement, (December), 115-123.

Sternberg, R. J. (2005). The Theory of Successful Intelligence, 39(2), 189-202.

Turki, J. (2012). Thinking Styles " In Light of Sternberg's Theory " Prevailing Among the Students of Tafila Technical University and Its Relationship with Some Variables Educational Psychology Section, 2(3), 140-152.

Vale, I., \& Barbosa, A. (2017). The Importance of Seeing in Mathematics Communication, 12, 49-63.

Zhang, L. (2017). Thinking Styles and Modes of Thinking : Implications for Education and, (May 2002).

https://doi.org/10.1080/002239802096041 53 